\title{
WIZERUNEK KONTRURBANIZACJI W POLSCE NA PRZYKŁADZIE REPORTAŻY „DALEKO OD MIASTA” CECHY MIGRANTÓW, MOTYWY MIGRACJI I JEJ KONSEKWENCJE DLA WIEJSKIEJ PRZEDSIĘBIORCZOŚCI ${ }^{1}$
}

\begin{abstract}
Abstrakt. Celem artykułu jest scharakteryzowanie wizerunku kontrurbanizacji w Polsce, jaki pojawia się w cyklu reportaży „Daleko od Miasta” wyemitowanych w telewizji Domo+ w 2015 r. Tłem analiz jest naukowy opis procesu kontrurbanizacji. Prezentowany w wybranym cyklu reportaży wizerunek kontrurbanizacji uwypukla jej motyw związany z chęcią podniesienia przez migrantów jakości życia. Są to osoby o wysokim statusie zawodowym, w wieku zakładania własnych rodzin i wychowywania dzieci, których do zmiany miejsca zamieszkania skłoniły przede wszystkim zmęczenie wykonywaną pracą i miejskim stylem życia oraz pragnienie realizacji życiowej pasji. Migranci ci najczęściej stają się przedsiębiorcami, których działalność nierzadko posiada cechy nowatorskie. W tym wizerunku pomija się kwestię migracji wymuszonych złą sytuacją życiową migranta lub osób mu najbliższych. Eksponuje się również oddziaływanie migrantów na rozwój wiejskiej przedsiębiorczości, co nie zawsze stwierdza się w literaturze przedmiotu.
\end{abstract}

Słowa kluczowe: kontrurbanizacja, migracje na wieś, jakość życia, przedsiębiorczość wiejska.

\section{Wprowadzenie}

Proces kontrurbanizacji występuje w wysoko rozwiniętych krajach Zachodu już od lat 70. XX wieku. Przyjmuje się dwa sposoby definiowania tego procesu. Kontrurbanizacja sensu largo (utożsamiana z pojęciem dekoncentracji) rozumiana

* Dr, Katedra Socjologii Wsi i Miasta, Uniwersytet Łódzki, ul. Rewolucji 1905 r. nr 41, 90-214 Łódź, e-mail: katarzyna.zajda@uni.lodz.pl.

** Dr, Instytut Rozwoju Miast, ul. Cieszyńska 2, 30-015 Kraków, e-mail: mdej@irm.krakow. pl,magdadej@gmail.com.

${ }^{1}$ Prace nad artykułem prowadzone były w ramach projektu Polsko-Niemieckiej Fundacji na Rzecz Nauki pt. „Analiza europejskiej idei partnerstw miejsko-wiejskich i ich implementacji w Europie", realizowanego w latach 2015-2016 przez Instytut Rozwoju Miast w Krakowie i HafenCity Universität w Hamburgu. 
jest jako proces, w którym dochodzi do transformacji systemu osadniczego na poziomie krajowym lub regionalnym ze stanu koncentracji ludności do stanu jej dekoncentracji. W myśl tej definicji następuje wzrost obszarów pozametropolitalnych szybszy niż obszarów metropolitalnych (Champion, Vandermotten 1997). Z kolei kontrurbanizacja sensu stricte polega na migracjach ludności z obszarów o większej koncentracji w kierunku obszarów, gdzie ta koncentracja jest mniejsza (Mitchell, Bryant 2009; Dej, Zajda 2016: 52).

W Europie Środkowo-Wschodniej badania nad tym zagadnieniem prowadzone są rzadko (Brown, Schafft 2002: 243; Simon 2014: 117). Celem rozważań w niniejszym artykule jest scharakteryzowanie wizerunku kontrurbanizacji w Polsce, jaki pojawia się w wybranym cyklu reportaży, przez co rozumie się opisanie cech migrantów, motywów ich migracji oraz konsekwencji ich zmiany miejsca zamieszkania dla wiejskiej przedsiębiorczości. Przedmiotem socjologicznej analizy (prowadzonej za pomocą techniki jakościowej analizy treści) będzie cykl zatytułowany „Daleko od Miasta”, wyemitowany w telewizji Domo+ w 2015 roku, liczący 16 odcinków. Efektem analizy będzie opisanie wizerunku kontrurbanizacji w Polsce, jaki pojawia się w wybranym cyklu reportaży na tle cech tego procesu opisanych w anglojęzycznej literaturze przedmiotu. Pierwsza część artykułu zostanie poświęcona przeglądowi literatury przedmiotu dotyczącej procesu kontrurbanizacji, cech migrantów, motywów towarzyszących ich osiedlaniu się na peryferyjnych, słabo zaludnionych obszarach wiejskich (w kontekście subiektywnego wymiaru jakości życia) oraz konsekwencji ich zmiany miejsca zamieszkania dla rozwoju przedsiębiorczości na wsi. W drugiej części artykułu zaprezentujemy założenia badań własnych. Trzecia jego część zostanie poświęcona rezultatom analizy oraz ich podsumowaniu.

\section{Kontrurbanizacja - kto migruje i dlaczego?}

Liczna grupa badaczy analizuje cechy migrantów oraz motywy towarzyszące ich migracjom (m.in. Halliday, Coombes 1995; Wamsley, Epps, Duncan 1998; Herslung 2011; Bijker, Haartsen, Strijker 2012; Simon 2012; Mamonova, Sutherland 2015).

$\mathrm{Na}$ podstawie przeglądu literatury przedmiotu trudno mówić o jednym, spójnym wizerunku migrantów, których migracje wpisują się w proces kontrurbanizacji. Zaznacza się różnica między kontrurbanizacją w krajach wysoko rozwiniętych a kontrurbanizacją w krajach Europy Środkowo-Wschodniej, gdzie proces ten w większym stopniu mógł (i wciąż może) być powodowany przyczynami ekonomicznymi niż przyczynami związanymi z obranym stylem życia. Ważnym (choć oczywiście nie jedynym) powodem migracji ludności miejskiej na wieś było (i jest) tutaj bezrobocie w miastach powodowane wciąż dokonującymi się przekształceniami gospodarczymi okresu transformacji (np. likwidacją 
i upadkiem państwowych zakładów wydobywczych, przemysłowych i przetwórczych). Mieszkańcy miast, zwłaszcza posiadający korzenie wiejskie, migrują na wieś w poszukiwaniu źródła utrzymania (niezależnie od tego, czy jest nim rolnictwo, wykonywanie innej pracy czy dochody najbliższych krewnych) (Simon 2012: 123).

Z badań M. Simona (2012) wynika, iż na peryferyjnych obszarach wiejskich osiedlają się trzy kategorie migrantów (wyszczególnione na podstawie kryterium fazy cyklu życia): 1) osoby młode wychowujące dzieci; 2) osoby, których dzieci już opuściły dom rodzinny; 3 ) osoby w wieku przedemerytalnym lub będące już na emeryturze (tamże: 127).

U podłoża tych migracji leży bardzo wiele powodów. Wśród nich R. Bijker, T. Haartsen i D. Strijker (2012) (na podstawie badań własnych przeprowadzonych w 2009 r. w północnej części Holandii) zidentyfikowali takie, jak: (1) zawarcie małżeństwa z osobą mieszkającą na wsi; (2) chęć mieszkania poza miastem; (3) posiadanie domu na wsi, w którym poprzednio się zamieszkiwało; (4) zmiany w sytuacji zawodowej wymuszające poszukiwanie pracy na wsi; (5) więzi sąsiedzkie; (6) chęć wybudowania domu; (7) przejście na emeryturę; (8) rozwód skutkujący poszukiwaniem nowego mieszkania; (9) wysokie koszty utrzymania w mieście; (10) potrzeba zamieszkiwania blisko rodziny; (11) opuszczenie domu przez dzieci; (12) poszerzenie składu rodziny; (13) problemy zdrowotne (Bijker $\mathrm{i}$ in. 2012: 495). Motywy migracji cytowani autorzy dzielą na trzy grupy. Pierwsza odnosi się do jakości domów i środowiska osiedlenia. Tutaj o migracji decydują zarówno takie czynniki, jak chęć posiadania własnego czy większego domu², możliwość posiadania ogrodu, jak i cechy związane z jakością przestrzeni wsi - atrakcyjność krajobrazu, świeże powietrze oraz cechy mieszkańców danego obszaru - ich życzliwość, przyjacielskość, ale także niższy odsetek przestępstw czy konfliktów społecznych. W drugiej grupie motywów migracji znajdują się te związane $\mathrm{z}$ potrzebą przebywania $\mathrm{z}$ rodziną ( $\mathrm{w}$ tym przypadku migranci powracają na wieś zamieszkiwaną $\mathrm{w}$ przeszłości właśnie z rodziną), założeniem rodziny (migracje powodowane zawarciem związku małżeńskiego), ale też rozpadem rodziny (migranci wracają na wieś zmieniając miejsce zamieszkania na skutek rozstania z życiowym parterem). Trzecia grupa motywów migracji odnosi się do sfery zatrudnienia i edukacji, wiąże się ze zmianą pracy, chęcią zamieszkiwania jak najbliżej miejsca jej wykonywania, ale też specyficznymi potrzebami edukacyjnymi, które mogą być realizowane na wsi (np. edukacja związana z opieką nad końmi i jeździectwem) (Bijker i in. 2012: 491).

Nieco inną hierarchię powodów opuszczania miasta, na podstawie badań przeprowadzonych w latach 2010-2011 na wybranych obszarach wiejskich Czech, zidentyfikował M. Simon (2012: 130). Wśród nich wyszczególnił główne,

${ }^{2}$ Przewaga obszarów peryferyjnych, słabo zaludnionych wiąże się z niższą ceną, jaką należy zapłacić za posiadanie własnego domu z ogrodem (por. Foulkes, Newbold 2008). 
pierwszorzędne oraz dodatkowe (kierując się przekonaniem o tym, iż decyzjom o migracji przyświeca więcej niż jeden powód). Do głównych zaliczył: (1) potrzebę utrzymywania bliskich kontaktów z rodziną, przyjaciółmi; (2) chęć życia w zgodzie z naturą; (3) chęć otaczania się wysokiej jakości środowiskiem przyrodniczym oraz (4) zmianę składu rodziny. Wśród powodów dodatkowych znalazły się: potrzeba spowolnienia tempa życia; zniechęcenie do życia w mieście; chęć samorealizacji, w tym realizacji życiowej pasji, hobby (Simon 2012: 130; zob. Dej, Zajda 2016: 54-55).

\section{Kontrurbanizacja a jakość życia na wsi}

Wieś, niepodlegająca procesom suburbanizacji, to jest ulokowana poza strefami oddziaływania ośrodków miejskich wyższego rzędu, zarówno w polskiej, jak i zagranicznej literaturze przedmiotu opisywana jest poprzez pryzmat mniejszych możliwości zatrudnienia, mniejszej dostępności do instytucji służby zdrowia oraz instytucji edukacyjnych, szkoleniowych, gorszego wyposażenia w infrastrukturę drogową, wodociągową, kanalizacyjną (Stanny 2013; Gilbert, Colley, Roberts 2016: 37). W związku z tym można byłoby przypuszczać, iż to, co przyciąga migrantów, zwłaszcza na obszary określane mianem peryferyjnych, słabo zaludnionych, to nie wysoki poziom obiektywnego wymiaru jakości życia, na który składa się szeroko rozumiana infrastruktura wsi - począwszy od sieci drogowej, kanalizacyjnej, przez cechy rynku pracy, po dostępność placówek kulturalnych, opiekuńczych i edukacyjnych, w tym domów kultury, żłobków, przedszkoli i szkół (por. Pukelien, Starkauskiene 2015), ale raczej utożsamianie migracji z wyższym poziomem subiektywnej jakości życia, to jest subiektywnego zadowolenia z życia jako pewnej całości. Deficyty infrastrukturalne wsi nie muszą negatywnie oddziaływać na poziom zadowolenia z życia jej mieszkańców (Shucksmith i in. 2009: 1288). Badania M. Simona (2012: 136-137) wskazują, iż $\mathrm{w}$ proces kontrurbanizacji wpisują się migracje osób, które motywowane są chęcią podniesienia jakości życia przede wszystkim w jej wymiarze subiektywnym i to mocno spersonalizowanym, przez co należy rozumieć fakt, iż te osoby nie poszukują specyficznych, pozytywnie waloryzowanych cech wsi i jej mieszkańców, a raczej bardzo ogólnych, bliżej nieokreślonych warunków do samodzielnego podniesienia własnej jakości życia.

\section{Kontrurbanizacja a wiejska przedsiębiorczość}

Choć nie sposób omówić wszystkich potencjalnych relacji między kontrurbanizacją a chociażby wybranymi aspektami subiektywnie określonej jakości życia, warto pochylić się nad problemem wpływu migracji tych osób na rozwój wiejskiej 
przedsiębiorczości. Subiektywnie określona jakość życia wiąże się bowiem z wykonywaną pracą (Pukelien, Starkauskiene 2015). Innymi słowy, elementem wpływającym na subiektywne poczucie jakości życia, zadowolenie migrantów ze swojego życia jako pewnej całości, jest wykonywana przez nich praca. Na czym polega ta praca, czy jest to praca najemna czy praca na własny rachunek, a jeśli tak, to czy wpływa ona na rozwój wiejskiej przedsiębiorczości?

Przegląd literatury przedmiotu (zaprezentowany w poprzedniej części pracy) dowodzi, iż bezpośrednim powodem migracji na wiejskie obszary peryferyjne rzadko jest chęć podjęcia pracy na wsi. Jak podkreśla L. Herslung, migranci miejscy rzadko rozpoczynają prowadzenie własnej działalności gospodarczej zaraz po osiedleniu się; na podjęcie tej decyzji potrzebują czasu, który wykorzystują na sprawdzanie możliwych opcji pozyskiwania dochodu (2011: 241). Podjęcie tej działalności jest konsekwencją: (1) pragnienia bycia aktywnym zawodowo (i wykorzystywania wcześniej nabytych kwalifikacji i umiejętności); (2) krytycznej oceny szans wykonywania pracy najemnej na lokalnym rynku pracy; (3) złych doświadczeń związanych z próbami dojeżdżania do pracy w pobliskim mieście; (4) niechęci do przekwalifikowania się (Herslung 2011: 248). Z badań tej autorki wynika, że profil działalności gospodarczej nie jest bezpośrednio związany z pracą, jaką migranci wykonywali mieszkając w mieście. Owszem, wykorzystują oni w niej nabyte wcześniej kwalifikacje i umiejętności, ale częściej własna działalność dotyczy ich hobby czy aktywności podejmowanej w czasie wolnym (ogrodnictwo, projektowanie ubrań, organizacja imprez kulturalnych, wycieczek, kursów językowych, świadczenie tzw. doradztwa życiowego - life coaching - czy usług terapeutycznych). Działalność gospodarcza tych migrantów miejskich zorientowana jest zarówno na społeczność lokalną, jak i na rynek miejski. Jej profil, choć może ulec zmianie, związany jest często z działalnością nowatorską dla wsi (Herslung 2011: 242).

Nowatorski charakter prowadzonej działalności wynika m.in. z cech kapitału ludzkiego, jakim dysponują migranci. D. Keeble i L. Nachum (2002: 74) migrantów z klasy średniej określają jako mobilnych profesjonalistów, którzy w działalności gospodarczej mogą wykorzystywać swoje doświadczenie, know-how, ale również sieci społeczne, których byli i są uczestnikami mimo zmiany miejsca zamieszkania. Ta nowatorska działalność nie zawsze okazuje się sukcesem i przynosi oczekiwany dochód. Przedsiębiorcy często redefiniują grupę swoich potencjalnych klientów, poszerzając ich krąg. Inne problemy towarzyszą przy tym przedsiębiorcom, którzy zorientowali swoją działalność na rynek lokalny (tutaj głównym problemem jest niski popyt na oferowane dobra i usługi), a inne tym, którzy swoją działalność zorientowali na rynek miejski (tutaj problemem jest odległość od ośrodków miejskich, ograniczająca szanse na spotkania face to face z potencjalnymi klientami, czasami niezbędne do zawarcia transakcji czy jej sfinalizowania) (Herslung 2011: 244, 252). Obie grupy przedsiębiorców modyfikują strategie działania w zależności od profilu swojej działalności i jej rynku docelowego. 
Prowadzona działalność gospodarcza migrantów może mieć różny wpływ na wiejską ekonomię, od dużego (w tym kontekście G. Bos worth (2010) ukuł sformułowanie „komercyjna kontrurbanizacja”, za pomocą którego podkreślił silne oddziaływanie nowo utworzonej działalności gospodarczej migrantów na lokalną ekonomię), po niewielki, w sytuacji kiedy w swojej działalności nie wykorzystują oni lokalnych zasobów, nie włączają do niej innych mieszkańców wsi, a sprowadzają ją do samozatrudnienia w formie telepracy (Herslung 2011: 251). Nie zawsze zatem utworzenie nowej działalności gospodarczej oznacza nowy impuls dla rozwoju wiejskiej gospodarki.

\section{Metodologia badań własnych}

Celem podjętych socjologicznych badań własnych było scharakteryzowanie wizerunku kontrurbanizacji w Polsce, jaki pojawia się w wybranym cyklu reportaży, przez co rozumie się opisanie cech migrantów, motywacji towarzyszących zmianie miejsca zamieszkania oraz konsekwencji ich migracji dla wiejskiej przedsiębiorczości.

Przedmiotem analiz uczyniono cyk1 reportaży zatytułowanych „Daleko od Miasta", zrealizowanych w latach 2014-2015 przez dziennikarkę Natalię Sosin, wyemitowanych przez telewizję Domo+ w 2015 roku. Cykl składa się z dwóch sezonów: pierwszego - w skład którego wchodzi 16 odcinków ${ }^{3}$, oraz drugiego - liczącego (w chwili przeprowadzania badania) 10 odcinków ${ }^{4}$. Kierując się kryterium wysycenia informacyjnego, uznano, iż udzielenie odpowiedzi na postawione pytania jest możliwe na podstawie analizy 16 odcinków wchodzących w skład pierwszego sezonu.

W badaniu, za M. Simon (2012: 121), przyjęto, iż kontrurbanizacja to migracja z miasta na wieś, która nie ulega procesowi suburbanizacji i która usytuowana jest na tyle daleko od najbliższego miasta, że znajduje się poza zasięgiem strefy 'commuting' - strefy dojeżdżania mieszkańców wsi do miasta celem zarobkowania.

Każdy z reportaży utrzymany jest w konwencji wywiadu swobodnego jego autorki z bohaterami. Każdy odcinek rozpoczyna się od wprowadzenia, ukazującego zarówno cel całego cyklu reportaży, jak i syntetycznie opisującego sylwetki

${ }^{3}$ W skład cyklu wchodzą reportaże o następujących tytułach: Lawendowe Pole, Siedlisko Pasieka, Karczma w Górach Izerskich, Glendoria-glamping na Warmii, Owocowy Dom, Siedlisko Polna Zdrój, Gospoda pod Wysokim Kamieniem, Oberża pod Psem, Stajnia Rosłońce, Kukówka na Kaszubach, Stajnia Zamczysk, Cydrownia Kwaśne Jabłko, Agroturystyka w Dolistowiu, Edukacyjny Park Owadów, Sosnowy Dwór w Bieszczadach, Rusinowa Polana.

${ }^{4}$ W skład cyklu wchodzą reportaże o następujących tytułach: Stara Kuźnia w Wolimierzu, Cisowy Zakątek, Pracownia witraży, ART Pension, Na ratunek wiejskim antykom, Folwark Wrzosówka, Pensjonat Szara Sowa, Siedlisko pod Lipami, Siedlisko Blanki, Agroturystyka w Jolinkowie. 
bohaterów i specyfikę odwiedzanego miejsca. Analizując poszczególne reportaże, poszukiwano odpowiedzi na poniższe pytania badawcze:

1. W jakiej fazie swojego cyklu życia migranci zdecydowali się na zmianę miejsca zamieszkania? W tym przypadku posłużono się kluczem kategoryzacyjnym zaproponowanym przez M. Simona (2012), wyróżniając: (1) młodych migrantów w wieku wychowywania dzieci; (2) migrantów, których dzieci opuściły już dom rodzinny; (3) migrantów w wieku przedemerytalnym lub przebywających na emeryturze.

2. Jaki zawód wykonywali migranci przed osiedleniem się na wiejskich obszarach peryferyjnych?

3. Jakie motywy towarzyszyły ich migracji? W tym przypadku posłużono się kluczem kategoryzacyjnym zaproponowanym przez Bijker, Haartsen, Strijker (2012: 490-491), którzy wyróżnili motywy związane z: (1) jakością domów i środowiska osiedlenia; (2) potrzebą przebywania z rodziną; (3) potrzebą zatrudnienia i edukacji.

4. Jaką pracę wykonują migranci po zmianie miejsca zamieszkania - najemną czy na własny rachunek, czy jest ona w jakiś sposób powiązana z zawodem, który wykonywali w miastach?

5. Jeśli migranci podjęli własną działalność gospodarczą, to jaki jest jej profil, czy można określić go mianem „nowatorskiego dla wsi”?

6. Jeśli migranci stali się przedsiębiorcami, to czy zatrudniają jakieś inne osoby? Czy są to osoby z rodziny czy może spoza jej kręgu?

7. Kto stanowi rynek docelowy prowadzonej przez nich działalności - przede wszystkim społeczność lokalna czy też jest to rynek ponadlokalny?

W badaniu wykorzystano technikę analizy treści, którą O. Holsti definiuje jako technikę wnioskowania o zbiorze przekazów na podstawie systematycznego i obiektywnego identyfikowania ich skoncentrowanych, charakterystycznych cech (Holsti 1969, za: Pisarek 2008: 245). Uwagę skoncentrowano na jednym z wyróżnionych przez B. Berelsona kryteriów analizy źródeł zastanych, to jest na charakterystyce treści przekazu ${ }^{5}$ (Berelson 1952).

\section{Rezultaty badań własnych}

\subsection{Cechy migrantów (bohaterów cyklu reportaży) oraz ich motywy migracji}

Bohaterami cyklu są przede wszystkim młode osoby, najczęściej pozostające w stałym związku, wpisujące się w kategorię młodych migrantów wychowujących dzieci. Tylko w jednym przypadku bohaterami są osoby w wieku emerytalnym.

${ }^{5}$ Do pozostałych kryteriów Berelson zaliczył: charakterystykę formy przekazów, charakterystykę nadawcy, charakterystykę odbiorców, charakterystykę efektów przekazu. 
Małżeństwa cechują się różnym stażem, niektóre wychowują dzieci będące w wieku kilku lat, inne dzieci nastoletnie. W trzech przypadkach bohaterami są młode osoby bezdzietne.

W omawianym cyklu reportaży uwypuklono wysoką pozycję zawodową migrantów. Są to przede wszystkim osoby bardzo dobrze wykształcone, specjaliści z różnych branż, zarówno osoby świadczące wcześniej pracę najemną: brokerzy, specjaliści od PR w korporacjach, copywriterzy, architekci, jak i osoby pracujące na własny rachunek: właściciele obiektów gastronomicznych, firm budowalnych, agencji reklamowych.

Osoby te pytane o bezpośrednie powody swojej „ucieczki z miasta” (którym była zarówno Warszawa, Kraków, ale też Berlin czy Nowy Jork) wskazywały na kilka. Najczęściej wymieniano zmęczenie wykonywaną tam pracą zawodową. Było ono powiązane ze zmęczeniem miastem jako miejscem życia - hałaśliwym, zatłoczonym, opisywanym poprzez pryzmat specyficznego stylu życia, którego wyznacznikiem były rywalizacja, pośpiech, ale też zbyt wiele pokus czy zbędnych możliwości wyboru.

Dla niektórych migrantów (bohaterów 4 z 16 odcinków) opuszczenie miasta było dość długim procesem, którego początek wiązał się z kupnem działki, gdzie spędzali wakacje pod namiotem, czy domku letniskowego, który z czasem przekształcali w całoroczny: „W letnim domu na Warmii coraz więcej spędzali czasu tadujac baterie, które coraz szybciej wyczerpywaty się w warszawskich biurach. W końcu wynieśli się na dobre" (Glendoria-glamping na Warmii). Wizerunek zamieszkiwanego wcześniej miasta spowodował, że zdecydowana większość bohaterów cyklu nie odczuwała już żadnej więzi z byłym miejscem zamieszkania, a wizyty w mieście traktowała jako przykrą konieczność: „Kiedy wracam do Warszawy i nie moge sobie pozwolić na takie życie zgodne z rytmem natury jak tutaj, to boleśnie to odczuwam - bólem głowy, zmęczeniem, takim rozdrażnieniem, bardzo szybko tapię warszawskiego nerwa i zaczynam głośniej mówić, szybciej mówić, mam wrażanie, że ciśnienie mi skacze" (Siedlisko Polna Zdrój). Miasto stawało się przestrzenią obcą, do zwiedzenia w ciągu jednego lub kilku dni, którą chętnie się opuszcza, by wrócić do domu: „Do dużego miasta bardzo chętnie, raz na dwa miesiace, wakacje, [...] ale... nie, nie, duże miasto na pewno nie, to już nie dla mnie, to już dla mnie za głośno, za szybko" (Siedlisko Polna Zdrój). Dla wszystkich migrantów ich obecne miejsce zamieszkania było miejscem, a nie tylko przestrzenią, którą chętnie zamieszkują, do której zawsze chętnie wracają: „Po prostu ja pokochałam to miejsce, to miejsce jest moim domem, a Warszawa już nim nie jest. Jak tam wracam i jeżdżę po ulicach, które kiedyś byty dla mnie bardzo bliskie $i$ drogie, to $w$ tym momencie juz nic dla mnie nie znacza. To jest moja rodzina, to jest mój dom i tak naprawdę moje miejsce w życiu" (Rusinowa Polana).

Znamienne jest, iż zasiedlane przez migrantów wsie (najczęściej ulokowane na obszarze Warmii i Mazur, Bieszczadów, rzadziej Podlasia, Pomorza, Mazowsza) zyskiwały status miejsca przede wszystkim przez więź bohaterów z własną 
rodziną, rzadziej (choć i te przypadki nie były odosobnione) z ich mieszkańcami. To, co cenili sobie migranci miejscy w nowym miejscu zamieszkania, to cisza i spokój, utożsamiane z brakiem bliskiego sąsiedztwa. Prezentowane w cyklu reportaży domy zasiedlane przez nich często nie sąsiadowały z innymi domostwami, były otoczone czy to lasem, czy polem uprawnym, niekiedy oddzielone od innego domostwa strumieniem. Niemniej w tych odcinkach, w których pojawił się wątek sąsiedztwa, instytucja sąsiada była ukazywana w bardzo pozytywny sposób. Sąsiad był tym, który pomagał naprawić popsuty piec, informował o tym, że konie uciekły, ale też świadczył pomoc, uczestnicząc w remoncie domu czy w pracach ogrodniczych. Był to sąsiad, którego obdarzano zaufaniem, którego szanowano i na którym polegano. Z takim sąsiadem spisywano transakcje kupnasprzedaży na „małej karteczce” (Oberża pod Psem) albo któremu dawano słowo, że zapłaci się za kupioną działkę wtedy, kiedy będzie to możliwe (Agroturystyka w Dolistowiu). Ten sąsiad z czasem mógł stać się nawet przyjacielem rodziny: „My mamy niesamowite szczęście, że takich fajnych ludzi udało nam się spotkać tutaj we Włodowie" (Cydrownia Kwaśne Jabłko). Cechą sąsiadów była również tolerancyjność. Nawet jeśli zauważali jakieś „obce” elementy stylu życia u nowo przybyłych, to akceptowali je, a nawet próbowali naśladować: „Jestem biegajacym wioskowym dziwadtem, ale jest coraz lepiej, sasiadka - już widziałem - zaczęla uprawiać nording woking" (Owocowy Dom).

Powodem migracji na dany obszar migrantów nie były jego znaczące i unikatowe walory przyrodniczo-krajobrazowe. Co prawda, bohaterowie cyklu osiedlali się w regionach atrakcyjnych turystycznie, takich jak Bieszczady czy Warmia i Mazury, ale poza dwoma wyjątkami atrakcyjność przyrodniczo-krajobrazowa nie była czynnikiem przesądzającym o migracji czy wyborze tej, a nie innej jej lokalizacji. W dwóch przypadkach migranci byli zdecydowani osiedlić się tylko w Bieszczadach. Dla bohaterów odcinka „Agroturystyka w Dolistowiu” na tym obszarze istniała możliwość prowadzenia profesjonalnych obserwacji gwiazd, na niebie niezanieczyszczonym światłem przemysłowym (jeden z bohaterów tego odcinka profesjonalnie zajmował się obserwacją nieba i w tym celu ze Słowacji przeprowadził się w tę część Polski). Bieszczady były również miejscem docelowym bohaterów odcinka pt. „Sosnowy Dwór w Bieszczadach”, którzy utożsamiali je z pięknym końcem świata, który cechuje się doskonałymi warunkami przyrodniczo-krajobrazowymi do jazdy konnej.

Drugim najczęściej wymienianym powodem migracji z miasta była chęć znalezienia miejsca, w którym będzie można realizować życiową pasję. Najczęściej było nią jeździectwo (ta pasja cechowała bohaterów aż 3 odcinków), a więc pragnienie posiadania własnej stajni, trenowania koni, przebywania z nimi w wymiarze większym niż kilka godzin w tygodniu. Do innych pasji należało zainteresowanie średniowieczem jako epoką, jej specyfiką, unikatowością, zwłaszcza muzyką tamtego czasu i zwyczajami rycerskimi. Bohaterowie jednego z odcinków (Oberża pod Psem) pasję odkryli wkrótce po przeprowadzce na wieś - a była nią 
architektura wiejska. W związku z tą pasją utworzyli własne muzeum, ratując od rozbiórki wiele budynków. W tym celu stworzyli stowarzyszenie, którego jednym z celów działania było (i jest) informowanie lokalnej społeczności o walorach lokalnej architektury. O efektach swojej działalności w stowarzyszeniu bohaterowie tego odcinka opowiadali w następujący sposób: „Póki jesteśmy grupa nieformalna, to nie mamy żadnego wptywu na podejmowanie żadnych decyzji... no i postanowiliśmy założyć stowarzyszenie, wiele ładnych obiektów dzięki temu istnieje. Cała nasza okolica - co by nie mówić - wiele osób zrozumiało, wiele osób już wie, że nie zniszczy swoich domów i ceni je sobie, ta świadomość mocno wzrosta" (Oberża pod Psem).

Najmniej znaczącymi powodami migracji były te związane z poszerzeniem rodziny o nowych członków, tj. dzieci, i te związane z poszukiwaniem miejsca wykonywania pracy. Tego rodzaju powody towarzyszyły bohaterom tylko dwóch odcinków - w jednym (Edukacyjny Park Owadów) para bohaterów zdecydowała się na opuszczenie Nowego Jorku po narodzinach pierwszego dziecka, uznając, iż nie jest to odpowiednie miejsce do wychowywania dzieci. W drugim (Oberża pod Psem) bohaterowie poszukiwali towaru, który mogli sprzedać. Dotarli do miejsca, w którym go produkowano i uznali, że zamiast kupować ten towar, mogą go sami produkować, kupując działkę i zakładając farmę.

\subsection{Konsekwencje migracji dla wiejskiej przedsiębiorczości}

Zdecydowana większość bohaterów reportaży pt. „Daleko od miasta” po osiedleniu się na wsi zaczęła prowadzić własną działalność gospodarczą. Wśród niej znalazły się produkcja lawendy, gryki, cydru, przetworów owocowych, prowadzenie stajni (łącznie z treningiem koni) oraz (najczęściej obierana) działalność agroturystyczna oferująca gościom nie tylko zakwaterowanie, własną kuchnię, ale również takie atrakcje, jak: jazda konna, profesjonalna obserwacja nieba, obcowanie ze strusiami, spa czy zamieszkiwanie w luksusowych namiotach. Szczególną uwagę zwracają takie nowatorskie działalności gospodarcze bohaterów cyklu, jak: (1) Edukacyjny park owadów, zaprojektowany przede wszystkim z myślą o grupach zorganizowanych (głównie szkolnych) oraz turystyce indywidulanej rodzin z dziećmi. W parku tym zwiedzanie połączono z ekspozycją sztucznych wizerunków owadów o bardzo dużych rozmiarach. Migranci samodzielnie stworzyli ścieżkę edukacyjną, a w oprowadzaniu wycieczek uczestniczyły również ich dzieci; (2) Gospoda pod Wysokim Kamieniem - XVIII-wieczny obiekt agroturystyczny odrestaurowany w nawiązaniu do średniowiecza, dedykowany przede wszystkim grupom rekonstrukcyjnym, tanecznym, śpiewaczym, których działalność i twórczość nawiązuje do tamtej epoki; (3) Glendoria-glamping na Warmii - luksusowy kemping, w skład którego wchodzi zespół namiotów pozostających w znacznej odległości od siebie z własnym węzłem sanitarnym oraz (4) Oberża pod Psem, przebywanie w której łączy się ze zwiedzaniem utworzonego przez 
migrantów muzeum zabytkowych budynków regionu (zespół budynków jako zespół architektury drewnianej został wpisany przez wojewódzkiego konserwatora zabytków do rejestru zabytków).

Nowi wiejscy przedsiębiorcy wykorzystywali w swojej działalności uprzednio nabyte doświadczenia, kwalifikacje i umiejętności, ale również zostali ukazani jako pasjonaci, dbający o każdy szczegół świadczonych przez siebie usług czy produkowanych dóbr. Bohaterowie odcinka pt. „Siedlisko Polna Zdrój” nabyli zabudowania znajdujące się w bardzo złym stanie, zrekonstruowali je dużym nakładem pracy wykorzystując różne zastane zasoby, np. 200-letni piaskowiec, który bardzo trudno było poddać obróbce, lub stare belki przejazdowe pochodzacee ze stodoły, zbudowane z 200-letniej dębiny, którą trudno było oczyścić i poddać obróbce $-\mathrm{z}$ niej powstały stół i balustrady w obiekcie. Jeden z bohaterów w następujący sposób opowiadał o odtwarzaniu zakupionych budynków: „To, co lubię, to odzyskać, uratować i budować zupetnie nowa jakość, ale też z elementów, które sa autentyczne, jak np. stare przedwojenne drzwi, poddane gruntownemu remontowi, renowacji, od nich sie zaczęło, do nich została zaprojektowana cała reszta”. Bohater odcinka „Gospoda pod Wysokim Kamieniem” spisał historię budynku pochodzącego z XVIII w., zakupionego dzięki uprzejmości zaproszonej niemieckojęzycznej poprzedniej właścicielki tegoż budynku. Właściciele „Glendorii" zaadaptowali na działalność starą stodołę, zaś małżeństwo, które stworzyło „Oberżę pod Psem”, ratowało od rozbiórki stare chaty, z czasem tworząc z nich własne muzeum: „Poczatkowo to miat być tylko materiat budowlany, ale jak się zaczęliśmy przygladać, jak to jest wybudowany ten dom, że to jest ładny w sumie budynek, stwierdziliśmy, że po co mamy go psuć, po co mamy to wykorzystywać jako materiat budowalny, przestawimy go w całości, ponumerujemy belki i przestawimy".

Migranci miejscy (bohaterowie reportaży) nierzadko eksperymentowali, zanim zdecydowali o profilu własnej działalności gospodarczej. Najczęściej ich pomysł na działalność wiązał się po pierwsze z nowo obranym stylem życia, w który wpisywały się takie cechy jak bliskość rodziny, natury, dbanie o zdrowie, brak pośpiechu, po drugie z osobistymi zainteresowaniami, hobby, po trzecie z dobrze rozpoznanymi potrzebami rynku. Przykładem jest tu zarówno produkcja ekologicznej gryki jako zboża bezglutenowego, na który to gluten uczulonych jest coraz więcej osób, lawendy o właściwościach leczniczych (tzw. medycyna naturalna), cydru - napoju alkoholowego tworzonego wskutek procesu fermentowania jabłek pochodzących (w przypadku tej działalności) z okolicznych, ekologicznych sadów. Połączyć pasję, nowy styl życia i pracę postanowili również bohaterowie reportaży będący miłośnikami koni.

Nie wszyscy z bohaterów reportaży, którzy stali się wiejskimi przedsiębiorcami, zatrudniali pracowników. Często (tak jest w 6 przypadkach) działalność gospodarczą prowadzili samodzielnie, wykorzystując potencjał własnej rodziny. Zatrudniali pracowników (przynajmniej sezonowo) ci przedsiębiorcy, którzy po 
pierwsze zajmowali się produkowaniem i przetwarzaniem dóbr: lawendy, gryki, cydru, owoców - traktując ich niemal jak przyjaciół domu, o których się dba (np. serwując domowe obiady), którym się ufa i na których się polega (proces powstawania więzi między migrantami-pracodawcami a pracownikami został szczególnie opisany w odcinku pt. „Cydrownia Kwaśne Jabłko”). Drugą grupą nowych wiejskich pracodawców byli właściciele stajni koni, którzy również tę działalność traktowali jak biznes rodzinny: „Ludzie dojeżdżaja, część mieszka u mnie tutaj w stajni, a cała reszta dojeżdza, w tej chwili ja moge powiedzieć, ̇̇e to jest taka moja rodzinna firma, bo syn pracuje u mnie, moja jedna córka, druga, która jeszcze chodzi do szkoły, syna dziewczyna pracuje u mnie, córki chłopak, i tak kilka jeszcze osób z zewnątrz. Generalnie jest to, jak chyba każda stajnia, duża rodzina. Jak ktoś nie pasuje do tej uktadanki i sa zgrzyty, to jak w stadzie wilków jest eliminowany. Jeden musi na drugim polegać".

Rynek docelowy działalności migrantów był przede wszystkim rynkiem pozalokalnym - oferta agroturystyczna była skierowana zwłaszcza do osób spoza miejscowości czy nawet regionu zamieszkania, głównie mieszkańców miast, podobnie jak bohaterowie reportaży zmęczonych jego stylem życia, lub osób posiadających tę samą pasję. Oferta przedsiębiorców produkujących i przetwarzających dobra również wykraczała poza rynek lokalny, a jej odbiorcami były osoby, którym zależało na zdrowej żywności i naturalnych środkach leczniczych. Bohaterowie reportaży w swojej działalności wykorzystywali różne zasoby lokalne, czyniąc z nich walor prowadzonej przez siebie działalności. Ich spektrum (prezentowane w całym cyklu) było ogromne - od rozgwieżdżonego nieba, przez ekologiczne sady ze starymi odmianami jabłek, po zabytkową architekturę i piękno krajobrazu. W prezentacji tych zasobów dominowały jednak te naturalne, a nie ludzkie. Oceniając całokształt wpływu nowych działalności gospodarczych na wiejską przedsiębiorczość, należy zaznaczyć, iż zdecydowana większość z migrantów uruchamiając własne działalności gospodarcze, w jakichś sposób wykorzystywała zasoby lokalne, oddziaływała na lokalny rynek pracy, oferując (chociażby sezonowo) nowe miejsca pracy, ale też tworząc nowe, niesformalizowane sieci wymiany, które w przyszłości mogą przekształcić się w nowe działalności gospodarcze, czego przykładem jest kupowanie niektórych z potrzebnych produktów od miejscowych rolników.

\section{Podsumowanie}

Wizerunek kontrurbanizacji w prezentowanym cyklu reportaży upodabnia ją do tej, jaka ma miejsce w krajach zachodnich oraz niektórych krajach Europy Środkowo-Wschodniej. Po pierwsze, migrantami stają się osoby, które dobrowolnie podjęły decyzję o opuszczeniu miasta. Ich migracja nie była wymuszona złą sytuacją życiową, brakiem możliwości zarobkowania w mieście, nie są to 
„uciekinierzy miejscy” ani osoby, które do migracji zmusiła sytuacja rodzinna. Są to osoby, które na różnym etapie swojego życia podjęły decyzję o tym, iż dalsze życie chcą wieść na wsi. Po drugie, celem ich migracji było podniesienie subiektywnego wymiaru jakości życia. Nie jest to więc kontrurbanizacja ekonomiczna, tylko ta określana w literaturze mianem life-style driven counterurbanisation. Bohaterowie reportaży, osiedlając się na wsi, nie poszukiwali przede wszystkim nowej pracy, dochodu, źródła utrzymania. Nie zwracali też uwagi na obiektywne wymiary jakości życia, tj. np. na dogodną sieć komunikacyjną, rozbudowaną infrastrukturę wodociągową, gazową czy kanalizacyjną. Wprowadzali się często do budynków niemal w stanie surowym zamkniętym, ogrzewając domy tylko kominkami, doświadczając braków prądu, czerpiąc wodę z pobliskich studni, a mimo to deklarowali podwyższenie jakości swojego życia. Na tę jakość składał się nowy styl życia, którego elementami były: spędzanie czasu z najbliższymi, blisko natury, z dala od zatłoczonego sąsiedztwa, realizacja życiowej pasji i zadowolenie $\mathrm{z}$ tego, co się osiągnęło. W wizerunku kontrurbanizacji, jaki został stworzony i zaprezentowany w wybranym cyklu reportaży, uwypuklono dwa motywy migracji, które trudno ulokować w jednej z trzech zastosowanych do analizy treści przekazu kategorii - to jest motyw zmęczenia wykonywaną pracą i miejskim stylem życia oraz motyw realizacji życiowej pasji. Nakazuje to poszerzenie wypracowanej przez Bijker, Haartsen, Strijker (2012) klasyfikacji o dwie grupy motywów, tj. (1) motyw związany ze zmianą stylu życia (odrzuceniem pewnych norm i wartości na rzecz wyeksponowania innych) oraz (2) motyw związany z samorealizacją.

Wizerunek kontrurbanizacji prezentowany $\mathrm{w}$ omawianym cyklu reportaży podkreśla jej pozytywne oddziaływanie na wiejską przedsiębiorczość. Nowi osadnicy wiejscy rozpoczynają własną działalność gospodarczą. Ich wysoki status zawodowy, połączony z zasobami wiedzy, doświadczeniem, kwalifikacjami i umiejętnościami, pozwala im (nawet po kilku porażkach) stworzyć nowe, atrakcyjne miejsce pracy, które często można określić mianem nowatorskiego. Jeśli jest to działalność agroturystyczna, to połączona z niestandardową ofertą typu obserwacja gwiazd pod okiem profesjonalisty i wykorzystaniem profesjonalnego oprzyrządowania, ulokowanie gości na obszarze własnego muzeum czy zakwaterowanie ich w luksusowych namiotach. Migranci stwarzają nowe miejsca pracy (chociażby sezonowo) oraz kształtują nowe sieci wymiany z innymi mieszkańcami, często nieformalne, które to w przyszłości tę przedsiębiorczość mogą pomóc rozwinąć.

Przeprowadzona analiza pozwoliła porównać wizerunek kontrurbanizacji w wybranym cyklu reportaży zrealizowanych w Polsce z cechami tego zjawiska zaobserwowanymi w innych krajach. Mając na uwadze oddziaływanie mediów na opinię publiczną, można założyć, iż omawiany cykl reportaży wśród jego odbiorców może upowszechnić przekonanie o związkach kontrurbanizacji z wiejską idyllą. Pozostaje pytanie, na ile ten wizerunek kontrurbanizacji jest zbieżny z rzeczywistym obliczem? Niewątpliwie odpowiedź na nie wymaga dalszych pogłębionych badań. 


\section{Bibliografia}

Berelson B. (1952). Content Analysis in Communication research. The Free Press, Glencoe.

Bijker R., Haartsen T., Strijker D. (2012). Migration to less-popular rural areas in the Netherlands: Exploring the motivations, "Journal of Rural Studies", no. 28, s. 490-498.

Bosworth G. (2010). Commercial counterurbanisation: an emerging force in rural economic development, "Environment and Planning", no. 42, s. 966-981.

Brown D., Schafft K. (2002). Leaving Athens: Narratives of counterurbanisation in time of crisis, "Journal of Rural Studies", no. 32, s. 158-167.

Champion A., Vandermotten C. (1997). Migration, counterurbanisation and regional restructuring in Europe, [w:] H. Blotevogel, A. J. Fielding (eds.), People, jobs and mobility in New Europe. John Wiley, Chichester, s. 69-90.

Dej M., Zajda K. (2016). Kontrurbanizacja i jakość życia na wsi, „Acta Universitatis Lodziensis”, Folia Sociologica, nr 57, s. 51-66.

Gilbert A., Colley K., Roberts D. (2016). Are rural residents happier? A quantitative analysis of subjective wellbeing in Scotland, "Journal of Rural Studies", no. 44, s. 37-35.

Halliday J., Coombes M. (1995). In Search of Counterurbanisation: Some Evidence from Devon on the Relationship between Patterns of Migration and Motivation, "Journal of Rural Studies", no. 11 (4), s. 433-446.

Herslund L. (2011). The Rural Creative Class: Counterurbanisation and Entrepreneurship in the Danish Countryside, "Sociologia Ruralis", vol. 52, Issue 2, s. 235-255.

Holsti O. (1969). Content Analysis for the Social Sciences and Humanities, Reading, MA, AddisonWesley.

Keeble D., Nachum L. (2002). Why do business service firms cluster? Small consultancies, clustering and decentralisation in London and Southern England, "Transactions of the Institute of British Geographers", no. 27, s. 67-90.

Mamonova N., Sutherland L. A. (2015). Rural gentrification in Russia: Renegotiating identity, alternative food production and social tensions in the countryside, "Journal of Rural Studies", vol. 42, s. 154-165.

Mitchell C. J. A., Briant C. R. (2009). Counterurbanization, [w:] R. Kitchin, N. Thrift (eds.), International Encyclopedia of Human Geography. Elsevier.

Pisarek W. (2008). Wstęp do nauki o komunikowaniu. Wydawnictwa Akademickie i Profesjonalne, Warszawa.

Pukeliene V., Starkauskiene V. (2015). Assessment of Changes in the Quality of Life of Emerging Economies in the Context of Developed Economies of the European Union, "Organizations and Markets in Emerging Economies", vol. 6, no. 2(12), s. 103-121.

Shucksmith M., Cameron S., Merridew T., Pichler F. (2009). Urban-Rural Differences in Quality of Life across the European Union, "Regional Studies", vol. 43 (10), s. 1275-1289.

Simon M. (2012). Exploring Counterurbanisation in a Post-Socialist Context: Case of the Czech Republic, "Sociologia Ruralis", no. 54 (2), s. 117-142.

Stanny M. (2013). Przestrzenne zróżnicowanie rozwoju obszarów wiejskich w Polsce. Instytut Rozwoju Wsi i Rolnictwa PAN, Warszawa.

Walmsley D. J., Epps W. R., Duncan C. J. (1998). Migration to the New South Wales north coast 1986-1991: Lifestyle motivated counterurbanisation, "Geoforum", no. 29 (1), s. 105-118. 
Katarzyna Zajda, Magdalena Dej

\title{
THE IMAGE OF COUNTERURBANIZATION IN POLAND ON THE EXAMPLE OF "FAR FROM THE CITY" TELEVISION REPORTS CHARACTERISTICS OF MIGRANTS, MOTIVES FOR MIGRATION, AND CONSEQUENCES FOR RURAL ENTREPRENEURSHIP
}

\begin{abstract}
The aim of this paper is to characterize the image of counterurbanization in Poland on the example of "Far from the city" television reports broadcast by the Domo+ television network in 2015. The analytical method used in this paper consists of media content analysis. Most migrants (presented in the reports) are high status professionals of child-bearing age whose migration to rural areas is prompted by growing dissatisfaction with their jobs and the urban lifestyle as well as an increasing desire to pursue life's passions. Many of these new migrants started their own businesses. These new rural entrepreneurs run their businesses by using local resources. The presentation of counterurbanization in "Far from the city" television reports omits any reference to out-migration due to poor quality of life in the city. These reports tend to emphasize the emergence of rural entrepreneurship due to counterurbanization, which is not always borne out by scientific studies.
\end{abstract}

Key words: counterurbanization, rural migration, quality of life, rural entrepreneurship. 